\title{
Integrating Library Resources Based on Textbook and Reference Book System: A Case Study
}

\author{
Gengxin Huang ${ }^{1}$, Liang Shi $^{2 *}$, Qing Yuan ${ }^{3}$, Hao Zhang ${ }^{4}$ \\ 1,2,3,4 Library of Huazhong University of Science and Technology, Wuhan, Hubei, P.R. China \\ *Corresponding author.Email: caesar@hust.edu.cn
}

\begin{abstract}
This paper is a case study that introduces the practice of the Library of Huazhong University of Science and Technology (HUST Library) on integrating resources. HUST Library has tried to build a Textbook and Reference Book System (TRBS), which intends to integrate as many related library resources and services as possible. This paper introduces the framework and functions of the system, discusses the encountered problems and challenges and aims to provide some reference for the construction of library digital resources.
\end{abstract}

Keywords: integration of resources, TRBS, utilization efficiency

\section{INTRODUCTION}

In this big data era, the internet creates enormous amount of information every day. The library digital resources are also accumulating at a fast speed. How to utilize the resources effectively so that the users could find what they need more efficiently is a research project facing the librarians all the time. Scholars domestic and abroad have studied how to integrate the digital resources so as to improve their utilization efficiency for many years. The definition of integrating digital resources is as follows: It's a process that restructures the distributed, unordered and heterogeneous digital resources into a new organism according to different patterns and strategies. ${ }^{[1]}$

The patterns of integrating digital resources could be classified into four types: OPAC System- Based; Navigation System-Based; Link System-Based and Cross-Database Retrieval- Based. ${ }^{2]}$ These four patterns all have their own strength and weakness. OPAC system is the earliest and the most welcomed integrating method in China. The core part of OPAC is the integration of book resources, but it could also extend its scope of integration to literature resources of other types. Navigation system could guide the readers through the library resources according to discipline classification, alphabetical order or literature type. It could organize the large amount of data sequentially and provide convenience for the readers to search and browse. However, these two methods could only integrate the resources at the form level, not at the content level. It could not provide individualized service. The Link
System and Cross-Database Retrieval could connect and integrate the resources at content level, but the integrating process is very complicated and required very high technology. ${ }^{[3]}$

The Library of Huazhong University of Science and Technology (HUST Library) has long been researching how to improve the efficiency of the library resources to better serve our readers. In recent years, HUST Library has tried to build a Textbook and Reference Book System (TRBS), which intends to integrate as many related library resources and services as possible. This paper introduces the framework and functions of the system, discusses the encountered problems and challenges and aims to provide some reference for the construction of library digital resources.

\section{AN OVERVIEW OF TRBS}

\subsection{The Original Intention of Building TRBS}

HUST Library has always intended to build a foreign language textbook and reference book database because of the following reasons. Firstly, our university tries to emulate world top universities and becomes world firstclass university one day. Thus we need to learn the curriculum, course information and textbooks used by the renowned foreign universities. Secondly, the foreign textbooks are very expensive and hard to retrieve. Thirdly, our teachers hope to have more access to foreign textbooks so that they could find suitable ones for their classroom use. The students could also improve their 
professional and English level if they could read original foreign language textbooks. Therefore, in order to better serve our teachers and students, HUST Library decided to construct a foreign language textbook and reference book database.

Besides foreign language books, the database planned to integrate as many related library resources and services as possible, such as related Chinese textbooks, related course information, interlibrary loan and document delivery service, etc. Hence we named the database TRBS.

\subsection{The Framework of TRBS}

Based on extensive study of related works and investigation of relevant websites, we designed the framework of TRBS.

\subsubsection{The Major Function Modules of the Web Page}

On the web page for the end users, we set the following function modules. Please see table 1.

Table 1. The major function modules of the web page

\begin{tabular}{|c|c|}
\hline Modules & Major functions \\
\hline Textbook information & $\begin{array}{l}\text { Click it and the user could enter the textbook search page, where it } \\
\text { provides simple search and advanced search. Realizing the function } \\
\text { of browsing according to the initial letter of the textbooks; Entering } \\
\text { the library's summon system. }\end{array}$ \\
\hline Discipline navigation & $\begin{array}{l}\text { Click it and the user could enter the discipline navigation page. All } \\
\text { the textbooks are categorized into Engineering, Science, Medicine, } \\
\text { Economic, Management and etc. The user could see all the } \\
\text { textbooks in this subject by clicking it, sequenced according to the } \\
\text { initial letter of the book name. }\end{array}$ \\
\hline Course information & $\begin{array}{l}\text { Click it and the user could enter the course information search page, } \\
\text { which is navigation-based search. Many top universities around the } \\
\text { world are listed here. Click the university name the user could see all } \\
\text { the departments and institutes of the university. Click the department } \\
\text { name, all the courses offered by the department could be seen. }\end{array}$ \\
\hline Users' recommendation & $\begin{array}{l}\text { Web form is adopted for this module. If the teachers or students know } \\
\text { some good foreign language textbooks, they could fill in the form to } \\
\text { recommend them to the library. }\end{array}$ \\
\hline Ask the librarians & $\begin{array}{l}\text { Web form is adopted for this module. If the teachers or students have } \\
\text { any questions or suggestions, they could write here and leave their } \\
\text { email address. The librarians will reply within } 48 \text { hours. }\end{array}$ \\
\hline Review of excellent textbook & $\begin{array}{l}\text { List the textbooks that have reviews and comments, which could be } \\
\text { browsed by discipline and initial letters of book names. }\end{array}$ \\
\hline Teaching aids information of some top universities & $\begin{array}{l}\text { List the teaching aids materials of some top universities, such as } \\
\text { teaching syllabus, courseware, lecture notes }\end{array}$ \\
\hline New books & List the new books added to the database within three months \\
\hline Popular textbooks & $\begin{array}{l}\text { List top } 500 \text { textbooks that are most frequently clicked in the } \\
\text { database. }\end{array}$ \\
\hline
\end{tabular}

\subsubsection{The Management System of the \\ The management system of the database is shown in Database}

Table 2. The management system of the database

\begin{tabular}{|l|l|}
\hline Modules & Major functions \\
\hline $\begin{array}{l}\text { Information } \\
\text { management system }\end{array}$ & $\begin{array}{l}\text { WYSIWYG editing is adopted by the system. The following functions should be } \\
\text { realized: combining text and graphics; posting documents of various formats; } \\
\text { satisfying the needs of copying word, excel or html webpage directly and } \\
\text { formatting automatically; supporting the entering, browsing, revising, deleting } \\
\text { and reviewing of a single text; excellent graphic management function; } \\
\text { supporting three types of documentation: regular document, external links and } \\
\text { external files. }{ }^{[4]}\end{array}$ \\
\hline Work flow management & $\begin{array}{l}\text { The delivery process of files, information or tasks according to certain pre- } \\
\text { defined rules between staff members should be automatic. The information } \\
\text { entered by the staff members should be approved and published under the } \\
\text { control of the workflow. }\end{array}$ \\
\hline Management of modules & Modules could be added, edited and deleted anytime. \\
\hline
\end{tabular}




\begin{tabular}{|l|l|}
\hline Hot search words & Hot search words of the database could be calculated. \\
\hline Log management & $\begin{array}{l}\text { The administrator's operation should be recorded and the operation log could } \\
\text { be searched and inquired by different means. Statistics information with chart } \\
\text { function could be generated. Users could export and delete the log(The } \\
\text { exported files could generate three types of format: EXCEL、XML、TEXT). }\end{array}$ \\
\hline Consultation module & $\begin{array}{l}\text { Reference librarians could see the readers' basic information and questions. } \\
\text { Reference librarian could reply the readers on the system platform. The system } \\
\text { could reply the information to the email address registered by the reader at the } \\
\text { same time. The reader could also log in the portal system to consult the reply. }\end{array}$ \\
\hline $\begin{array}{l}\text { Report of database } \\
\text { operation state }\end{array}$ & $\begin{array}{l}\text { The background program could detect the database operation state } \\
\text { automatically and set up a regular detection time. It could also automatically } \\
\text { check whether the database server is running smoothly or not and create } \\
\text { operation state log, dealing with the problem immediately when detected. In this } \\
\text { way, human inspection of the database is avoided and failure response time } \\
\text { could be highly enhanced. }\end{array}$ \\
\hline Identity authentication & $\begin{array}{l}\text { The authentication system of TRBS will keep consistent with that of the library's } \\
\text { portal websites. }\end{array}$ \\
\hline $\begin{array}{l}\text { Traffic analysis and } \\
\text { statistics }\end{array}$ & $\begin{array}{l}\text { The website traffic analysis software could effectively monitor the visits, the } \\
\text { number of users online and the statistics of the visitors. }\end{array}$ \\
\hline
\end{tabular}

(Note: WYSIWYG = what you see is what you get)

\subsubsection{The resources on TRBS}

Up to now, the total amount of resources on TRBS platform is listed as follows: 31910 foreign language textbooks; 64702 courses; 184404 teaching aids materials; 19887 comments.

\section{THE PRACTICE OF INTEGRATING MORE LIBRARY RESOURCES AND SERVICES INTO TRBS}

Through our research and investigation, we found that MeTel multi-media teaching resources database, a commercial database, almost satisfies our readers' information needs for world top universities' teaching resources. We decided to use MeTel as the basis of our TRBS, combining the data collected by ourselves, integrating multiple resources in our library and constructing a featured database that serves our teachers and students. Next, the types of resources we integrated into TRBS will be introduced.

\subsection{Integrating the Chinese Textbook Resources}

The CALIS university textbook and reference book database is co-constructed by many top university libraries in China. It has about 60000 e-books. We decided to integrate this database into TRBS. A "Related Chinese Textbook" link is set up on the textbook information search page of TRBS. Through the comparison of key words, the system could display Chinese textbooks related to the English textbook in the sequence of similarity. When the readers browse an English textbook, they could see several related Chinese textbooks on the same page. If they are interested in the book, they could click it and read it online.

\subsection{Integrating Domestic Universities' Course Information}

We collected the course information of some top Chinese universities. On the course information search page, a link of "related Chinese course information" is set up. Through the comparison of key words, the system could display the Chinese course information related to the English course in the sequence of similarity.

\subsection{Integrating Interlibrary Loan and Document Delivery Service}

We integrate the OPAC system and Summon discovery system of our library into TRBS too so that readers could know more about our library resources. Also, the interlibrary loan and document delivery service is embedded into TRBS to readers' convenience. For example, if the electronic textbook has its paper version in our library, the call number and the room number will be shown. If other universities have the paper version, then the interlibrary loan and document delivery service link will be provided. Thus the readers have one more way to get access to the document they need. Through the Summon discovery system, readers could get to know more resources related to the textbook.

In the future, we plan to integrate more library resources to enrich TRBS, such as CD resources, open access resources, etc. However, this involves technology like matching the metadata standard, which is difficult and requires more support of policy and fund to carry out. 


\section{CONCLUSION}

As a featured database of HUST library, TRBS evolves from a single foreign language textbook and reference book database to a database integrating various library resources of multi-sources. In this way, the utilization efficiency of the library resource is highly improved and readers are more convenient to get access to the information they need. This case study is only a first step of integration and we still have a long way to go. In the future, we could try to integrate different resources for certain purposes. In addition, we could begin to try to connect the data at content level, which is called aggregation, the future direction of integration. ${ }^{[5]}$

\section{REFERENCES}

[1] Wenfeng Ma, Integration of digital resources, [J] Journal of Library Science in China, Vol. 28, No. 4, 2002, pp.

64-67.

DOI :10.13530/j .cnki.jlis.2002.04.017

[2] Hui Sun, Research on library digital resources integration strategy based on discipline service in the background of big data[J], Intelligent Computer and Applications, Vol. 9, No. 6, 2019, pp. 302-304.

[3] Qing Liu, Qingrong Guo, Yuqiang Guo, Lin Jia, Integration of science resource and construction of subject information service system[J], Journal of Wuhan University of Technology(Information \& Management Engineering), Vol. 32, No. 1, 2010, pp. 96-99. DOI:10.3963/j.issn.1007-144X.2010.01.026

[4] Shengzhi Li, Research on the design and construction of the portal website of serviceoriented government[D], Dalian University of Technology, 2008, pp. 24-29.

[5] Lanjie Chen, Pengjuan Hou, Research on the reveal methods of digital literature resources relationships [J], Library, No, 2, 2015, pp. 41-45. 